\title{
ECONOMIC DIMENSIONS AND LEGAL REGULATION OF THE RECOVERY OF ALIMONY OBLIGATIONS FOR THE SUPPORT OF MINOR CHILDREN IN RUSSIA
}

\author{
Yulia A. Artemyeva \\ Peoples' Friendship University of Russia (RUDN University), Moscow, Russia
}

\begin{abstract}
Russia lags far behind other developed countries in all aspects of the regulation of alimony obligations. This research substantiates economic factors and the legal regulation of alimony obligations for minors in Russia, referring to other countries' experiences and distributing a questionnaire. Indicators of the parents' well-being, the satisfaction of the child's needs, and parents' participation in raising a child after a divorce was determined. Regression models were built reflecting the influence of the number of alimony payments, the indicator of parent's participation in raising a child, the opportunity costs associated with the choice made by each spouse in favour of the family and children, and the integral indicator of the effectiveness of alimony and its particular indicators. We determined that $21 \%$ of income for alimony is an optimal size to maximize the satisfaction of the child's needs and level the material damage of a parent who pays maintenance.
\end{abstract}

Keywords: Russia, alimony, parents' wellbeing, divorce, minor child's needs, legal regulation, economic dimensions of paying child alimony

DOI: http://dx.doi.org/10.15549/jeecar.v8i4.813

\section{INTRODUCTION}

The last 70 years in Russia have witnessed a steady and strong trend towards the reduction of marriages. Only at the beginning of 2021, had the number of marriages compared to the previous year decreased (by almost 19\%) and amounted to 5.3 per 1000 people (Federal State Statistics Service, 2021). At the same time, there was a rapid increase of $73 \%$, in the number of divorces in 2020, whereas for comparison, in 1950, the reported rate was only $4 \%$ (Fig. 1 ). According to the official data of the World Population Review 2021, Russia has the highest divorce rate in the world: 4.7 divorces per 1000 population (World Population Review, 2021).

Current demographic information indicates the existence of about 17 million families with children in the country. In contrast, a minor child is raised by only one parent in every third family and often without the former spouse's financial support (Federal State Statistics Service, 2021). Despite the direct legislative obligation to pay alimony (criminal and administrative sanctions are provided in the event it is not paid), the statistics of alimony non-payment remain extremely high. 

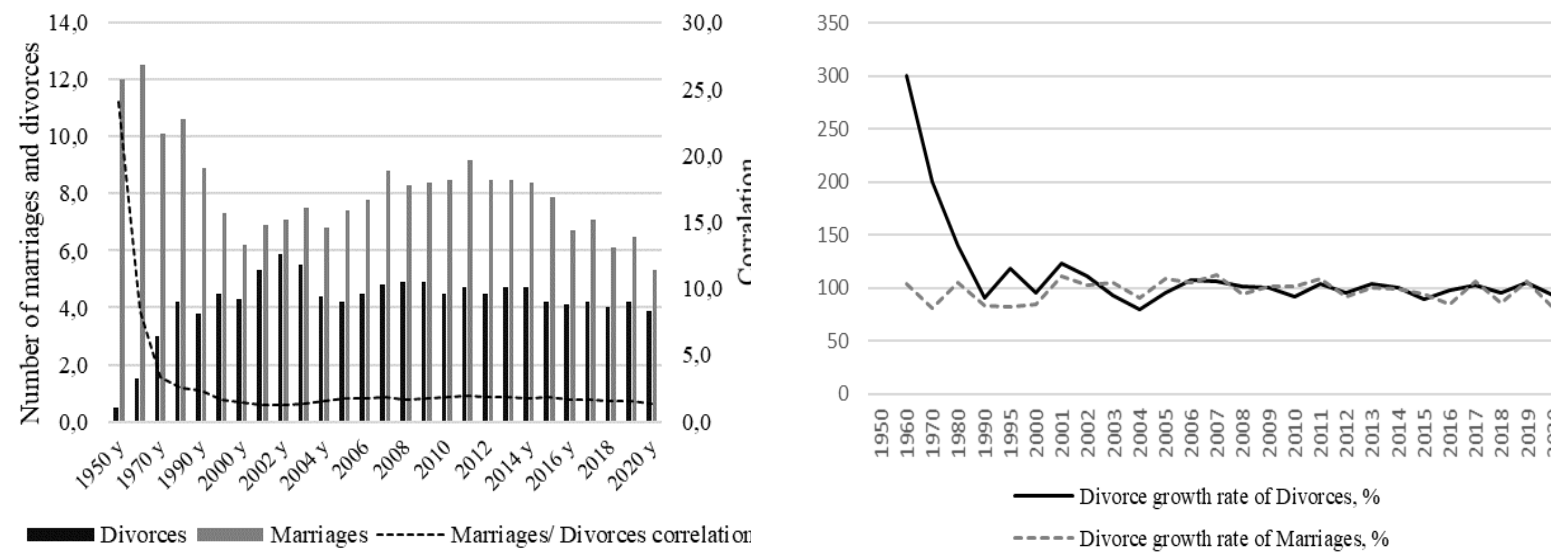

Figure 1: Retrospective analysis of the number of marriages and divorces in Russia

Source: Federal State Statistics Service (2021)

The share of enforcement proceedings, within which the rights to receive alimony are exercised, exceeded 80\% (Federal Bailiff Service, 2021). According to the latest official data, in 2021 in Russia every third alimony payer has refused to fulfill their obligations (Failure to pay child support, 2021). In early 2021, more than 1 million cases of non-payment of alimony (part 1 of article 157 of the Criminal Code of the Russian Federation (The Criminal Code of the Russian Federation, 2021)) with a total debt of more than 200 billion rubles were received (Neither ruble, nor penny. Why is it so difficult to get child support?, 2021).

One of the fundamental parent obligations is to support their minor children until their age of legal majority, which is on a par in importance with the obligations of their upbringing and development. Since the lack of funds in the family can negatively affect not only the child's physical condition but also their psychological development, the systematic non-payment of alimony becomes a destructive factor in the formation of a full-fledged personality and is not useful for society and the country's socioeconomic development. In addition, numerous studies have shown that the regular payment and amount of alimony have positive socioeconomic consequences by reducing poverty in the country (Hakovirta et al., 2019). Enforcing them in favor of children would reduce the risk of poverty for many minor children. For instance, paying alimony by former spouses to minor children's parents has reduced the poverty level by $21 \%$ in Australia and $14 \%$ in the UK (Hakovirta et al., 2019).

Each state creates its own instruments and approaches to understanding and measuring the children's well-being in single-parent families and the material well-being of a parent who makes alimony payments to adult children.

For instance, Germany is characterized by a well-thought-out practice of progressively scaling the amount of alimony payments: the more a parent earns, the more he pays. And the amount of alimony directly depends on the child's needs; that is, it is determined regarding the child's age. Older heirs receive larger sums than younger ones (Unterhaltsvorschussgesetz, 2021). The basis for calculating the amount of alimony is the Dusseldorf Table, which, with an accuracy within one euro, determines the income from which children of the corresponding age should be paid (Dusseldorf Table, 2021). At the same time, the amount of alimony is set strictly regarding the parent's financial situation, according to which the alimony is recovered. In any case, it must remain at least 1,100 euros if the parent works and at least 800 euros if a parent receives unemployment benefits (Dusseldorf Table, 2021). In general, alimony payers are divided into 11 groups depending on the amount of income. Alimony payments are issued up to the age of 18, and if the child receives higher education, even longer (Dusseldorf Table, 2021). 
According to official data in the United States, about $25 \%$ of children live in single-parent families (America's single-parent families, 2021). A child from an incomplete family is eligible for maintenance payments up to the age of 21 . The collection procedure differs from state to state (Alimony Laws by State, 2021). For instance, in New York, both parents' combined income level determines the amount of child support. One child accounts for $17 \%$ of the total income, two children for $25 \%$, three for $29 \%$, etc. A parent who does not live with a child pays $60 \%$ of the required amount if his income exceeds the income of his former spouse, or $40 \%$ if he earns less (New York Child Support Lawyer, 2021).

In France, the courts set child support liabilities. For divorcing parents, the judge will set the amount of child support along with contact arrangements. The judge requires child support agreements to be made when the divorce is by mutual consent and joint petition. The level of alimony for minor children living in single-parent families in France is usually set at the judge's discretion. In view of this, the Ministry of Justice has developed a reference table, which is a guideline for calculating the amount of alimony but is not mandatory if the parents were able to mutually agree (La pension alimentaire, 2021). When determining the amount of alimony to be paid, the parent's income is taken into account, from which the minimum subsistence rate is deducted. But this approach does not apply to parents who can pay monthly alimony exceeding $€ 5000$ (La pension alimentaire, 2021). The duration of the alimony payment is the same as in other developed countries, that is, until the child turns 18 , and the requirement is established to pay them if the child studies at a university.

In 2008, a reform was adopted in the United Kingdom to balance the support system for children in single-parent families. The child's alimony is determined in proportion to the parent debtor's net income after deducting taxes, insurance, and pension contributions. The basic rate of the contribution starts at $15 \%$ of the debtor's revenue for one child, $10 \%$ per child if there are two children, $8.3 \%$ per child for three children or more (Comparative Law and Practices in Child Maintenance, 2015). If the paying parent has, in addition, the custody of one or more children, a percentage is deducted from his net income to take this charge into account before any calculation: $15 \%$ of the net income is deducted for one child in care; $20 \%$ for two children; $25 \%$ for three children (Comparative Law and Practices in Child Maintenance, 2015). The parent stops paying maintenance when the child turns 16 or continues to pay until the age of 20 if the child studies a university.

In Australia, child maintenance is issued by the courts and applies to children living in singleparent families under the age of 18 (Beacon Family Law, 2021). Since the courts in the country have a fairly wide range of discretionary powers, as a rule, when calculating the amount of alimony, a wide range of factors are taken into account: the age of children and their number; children's needs and parents' ability to cover these costs; and the level of parents' income, as well as the time that each parent spends with the child, etc. (Australian Government, 2021).

Thus, the best practices for the collection of alimony in developed countries involve: taking into account the broadest possible range of factors when calculating the amount of alimony; accounting for the level of financial security of the alimony payer and their performance; and determining the system of standards for the general wellbeing of the child.

At the same time, tough measures to prevent alimony payment evasion can be considered a complementary factor in effective social support for minor children in single-parent families in the countries under review. For example, a person in arrears in child support cannot leave the country or can face an indefinite prison sentence (Citizen's Guide to U.S. Federal Law on Child Support Enforcement, 2020). In general, it can be said that the legislative and legal regulation of the recovery of alimony payments in the considered countries is quite effective since they are characterized by the lowest level of non-payment of alimony (Beaumont \& Mason, 2014). This allows ensuring a balance between the most complete satisfaction of the child's needs when the parents do not live together and minimizing the risk of deterioration in the material wellbeing of the alimony payer as much as possible (Hakovirta et al., 2019).

Russia lags far behind other developed countries in all aspects of regulating alimony 
obligations for the maintenance of minors. A common practice in the country is the judicial determination of the amount of alimony in shares of the salary or other income of the alimony payer: one-fourth for one child, one third for two children, and one half for three children or more. In view of the fact that in Russia, there is a fairly high level of unemployment and the practice of gray salaries (without paying social tax deductions) is widespread (annually, about $30-40 \%$ of Russians receive a gray salary; and the volume of the unofficial salary fund exceeds 10 trillion rubles), it is sometimes difficult to reliably determine the level of salary of a parent who pays alimony (Komrakov, 2021). In this case, alimony is awarded in the form of a fixed amount linked to the subsistence minimum (Kobrin, 2021). But this is not one of the main reasons for the low level of alimony payments in Russia. The difficulty is that the collection of alimony has long belonged to private law, and therefore there was no legal support to complainants. It was only when Russia ratified the UN Convention on the Rights of the Child (1989) that the state created a body obliged to seize funds from the debtor's income or property - the Federal Bailiff Service (2021). First of all, measures of administrative responsibility are applied to the debtor. Still, many also face criminal liability if the alimony is not paid for more than a year (The Criminal Code of the Russian Federation, 1996). Annually, bailiffs keep several hundred thousand files on alimony non-payment. But the number of cases that are completed by actual or voluntary enforcement (that is, the payment of money) remains almost unchanged. About 20\% of single mothers do not receive alimony, despite positive court decisions (Filippova, 2020). Among the tens of thousands of those convicted of alimony nonpayment, there are not only irresponsible fathers escaping alimony but poor and sick people who are unable to pay alimony and generally get out of the brink. For example, in 2019, 757 disabled people were convicted under Article 157; in 2020, their number was 442. Among those who were convicted in 2019, there were 26 people with group 1 and 2 disabilities; in 2020, there were 22 such people (Judicial Department at the Supreme Court of the Russian Federation, 2021). There are no data published on convicted people with group 3 disability in Russia. There are certainly ways to solve the alimony problem, as the above analysis of best practices in developed countries has shown, but Russia is in no hurry to develop them.

This study attempts to analyze the practice of economic aspects of the regulation of alimony payments and to systematize the main approaches to increasing the efficiency of regulation of alimony obligations for minors' maintenance in Russia. Russia has a unique opportunity to take this experience into account and use it to form effective legislation that will protect the victims' rights. While it is generally accepted that the economic and social consequences of divorce are critically dependent on whether there are any children involved in it, and how many are involved, empirical knowledge of such differences remains scarce. In this study, we present a comprehensive assessment of how the economic dimensions of child support can influence the effectiveness of divorce regulation. In the Results section, we have substantiated the factors that affect the alimony amount by questioning the members of single-parent families in Russia, the USA, France, and Germany. And we calculate the integral indicator of the effectiveness of alimony into account indicators of the well-being of parents and the satisfaction of the needs of children. Based on the econometric models, the optimal alimony amount is determined, which maximizes the integral indicator of the effectiveness of alimony obligations

\section{LITERATURE REVIEW}

As evidenced by the analysis of the literature, in practice the determination of the amount of alimony payments is based primarily on the determination of the cost of the needs of a child living in a single-parent family (Jeandidier \& Lim, 2015). The guiding approach here is the method of consumption units, based on the study of the child's daily life and the family's budget (Heggeness, 2020). Still, it does not determine the necessary contribution of parents regarding their financial situation and capabilities. Therefore, the question arises as to how to determine the necessary parental contribution in the form of alimony to maintain a decent life for the child? The most common approach seems to be a model for differentiating parental 
contributions based on their income distribution (Hakovirta et al., 2019; Van Winkle \& Leopold, 2021). This approach allows guaranteeing a minor child material wellbeing to the same extent as when reuniting a family. This approach contains a certain moral aspect that conflicts with the economic realities of family members that have broken up. Divorce implies a decrease in the standard of living of an incomplete family and doubling expenses for the parent who must pay alimony for a minor child (Jeandidier \& Lim, 2015; Van Winkle \& Leopold, 2021).

It should be noted that, given the dependence on the level of parental income and focus on meeting the needs of a minor child, methods for determining the alimony amount across countries are characterized by significant variability. The most universal key factors that are regarded when determining the alimony amount are the income of both parents (considering Russia, Germany, France when implementing the percentage model and the Melson Formula model in certain US states), the level of the child's wellbeing before the parents' divorce (the income shares model realized in the USA), social standards in the country (for example, minimum wage, living wage in Latvia, Sweden) (Hakovirta et al., 2019; Beaumont \& Mason, 2014; Jeandidier \& Lim, 2015; Morgan, 2021). At the same time, these models do not take into account the subjective component that characterizes the parents' contribution to the minor children's upbringing and the opportunity costs associated with the choice made by each spouse during a marriage in favor of the family and children (Jeandidier \& Lim, 2015; Pirtskhalaishvili et al., 2021). Opportunity costs are manifested in the fact that for the sake of the family and children, parents (mainly women) refuse to receive education, work, and career growth. It would affect the efforts made to find employment and achieve the existing level of wellbeing and prosperity in the long run. In this regard, the following hypotheses were formulated:

H1 - the alimony amount obligation is determined not only by the alimony amount but also by parents' participation in raising a child;

$H 2$ - the alimony amount deduction depends on the professional choice made by each spouse during marriage for the sake of union or for the sake of children, representing the opportunity costs of starting a family;

$\mathrm{H3}$ - an increase in the percentage of alimony deductions from the payer's income contributes to an increase in the level of wellbeing of the parent who keeps the child and leads to a decrease in the level of the alimony payer's wellbeing.

\section{METHODOLOGY}

Due to the subjective component of the studied subject area, the questionnaire method was applied as a technique for obtaining data. Divorced family members from Russia, the USA, Germany, and France took part in the survey. The USA, France, and Germany are characterized by variability in the applied models for determining the amount of alimony and developed legislation that regulates the alimony payment, whose experience can increase the validity of deciding on the amount of alimony in Russia.

The survey was carried out remotely from January to June 2021 and was voluntary and anonymous. The questionnaire (Google Form, 2021) consisted of questions regarding:

- Information about respondents (group 1) sex, age, country;

- The level of parents' wellbeing before and after divorce (group 2):

- Satisfaction with their level of wellbeing (indicator W5);

- The ability to meet their own needs due to their income ( WG);

- Opportunities to support the child due to their income ( W7);

- Welfare changes after the divorce (W8);

- Employment opportunities (W9);

- Having a stable job, which, like the previous indicator, affects the level of income in the future $(W 10)$;

- The level of meeting the child's needs before and after the parents' divorce (group 3): satisfaction of physiological needs (N11), material security (N12), the opportunity to attend sections, circles (N13), satisfaction with the participation of both parents in raising a child (N14), lack of feeling inferiority (N15), discomfort (N16) in 
connection with the parents' divorce, the dynamics of the child's wellbeing after the parents' divorce (N17);

- parents' participation in raising a child before and after the divorce (group 4);

- Assessing the degree of parental involvement in raising a child (R18), dynamics of participation activity after divorce $(R 24)$ and satisfaction with such participation on the part of the second spouse ( $R 27)$;

- Distribution of the time the child spends with parents (R19);

- Sacrifices that parents make to provide for and raise a child in marriage $(R 20)$ and after divorce: the sacrifice of career $(R 21)$ and free time (R22, R23), which, at significant expenses, creates the risk of an increase in the level of poverty: their own and the child;

- alimony paid $(R 28, R 30)$ and other financial assistance (R25), satisfaction with the amount of alimony received from the second spouse (R26), and reasons for non-payment (late payment) of alimony (R29).

Groups of questions were formed based on the analysis of legislation on the contractual regulation of alimony obligations in Russia, the USA, the EU countries, as well as scientific publications on this topic (Hakovirta et al., 2019; Beaumont \& Mason, 2014; Jeandidier \& Lim, 2015). The evaluation was carried out on a 5point Likert scale, where the score "1" corresponds to disagreement with the question (statement) of the questionnaire, "5" agreement (Maghlaperidze et al., 2021).

Divorced couples (men and women) with one joint child and no more children took part in the survey. The number of broken families participating in the survey was 485 from the United States, 391 from Germany, 318 from France, and 692 from Russia. This study focuses on studying the patterns of the formation of alimony obligations in families with one child, their impact on the level of well-being of parents and children, and the risk of poverty for members of broken families. Therefore, the criterion for selecting families for assessment was the presence of one joint child. If one of the spouses is divorced more than once but has one child, then the survey was aimed to study the respondent's wellbeing in the marriage in which there is a joint child and the respondent's participation in raising this child.

The representativeness of the sample population of respondents is evidenced by the number exceeding the minimum required -384 people for a general population (Taherdoost, 2017) and the representation of different states, countries, and regions within each country.

The reliability of the questionnaire was verified using Cronbach's alpha test. The value of this criterion for groups of questions was 0.82 for group 2; 0.79 for group 3; and 0.90 for group 4 . The indicated coefficients are in the range of 0.70.9 , which shows the questionnaire reliability, as well as the absence of questions that would be duplicated and give identical results (since the values of the coefficients do not exceed 0.9) (Hair et al., 2017).

A regression model was used in the EViews 10 program to determine the amount of alimony payments that would ensure a balance between meeting the minor child's needs and the divorced parents' wellbeing. The number of observations corresponds to the number of families studied (1886 observations). The indicators of parents' participation in the children's maintenance and upbringing after divorce and the opportunity costs of raising a child were used as independent variables. Following the hypotheses put forward, an increase in the amount of alimony leads to an increase in the welfare of the child and the parent who supports him, but on the other hand can lead to poverty of the parent paying alimony. Considering the multifaceted nature of the alimony payment policy and the opposite nature of the impact on the wellbeing of individual subjects of family relations, use of the integral indicator of the effectiveness of alimony obligations $(E F)$ as a dependent variable is proposed. This indicator is calculated based on the scores for the questionnaire questions concerning the level of parents' wellbeing (IW) and the level of satisfaction of the child's needs (IN) (formula 1). The coefficients of the relative importance of particular indicators in the integral model are determined based on expert assessments. For this, a group of experts was formed, consisting of members of the judicial collegiums of the Supreme Court of the Russian Federation, who deal with issues of legislative 
regulation of the procedure for paying alimony, and representatives of the Federal State Budgetary Institution "Center for the Protection of Children's Rights and Interests", whose activities are aimed at organizational and methodological support of the activities of this institution for the protection of children's rights. The total number of the expert group is 60 people. The experts were asked to rank the indicators of parents' wellbeing and the degree of satisfaction of children's needs in order of their importance in assessing the effectiveness of alimony obligations; a rank "1" corresponds to the highest significance of the indicator. The indicators $E F, I W, I N$ are calculated by formula (1):

$$
\begin{aligned}
& E F=I W+I N=\sum_{i=1}^{n} k_{i} \times W_{i}+\sum_{j=1}^{m} k_{j} \times \\
& N_{j}, \\
& k_{i(j)}=\frac{\mathrm{Rn}_{\max }-\mathrm{Rn}_{i(j)}+1}{\sum_{i=1, j=1}^{n, m} \mathrm{Rn}_{i(j)}}, \\
& n=\overline{5,10, m=\overline{11,17}}
\end{aligned}
$$

where $k_{i}, k_{j}$ are ratios of the relative importance of partial indicators of the effectiveness of alimony obligations;

$$
\begin{aligned}
& R n_{i(j)} \text { - rank of partial indicators; } \\
& R n_{\max }-\text { maximum rank of partial indicators. } \\
& R n_{\max }=13 \text {. }
\end{aligned}
$$

The possibility of using the results of expert assessment is confirmed by the experts' competence and the consistency of their opinions (the coefficient of concordance was 0.82).

Based on the constructed regression models, the optimal indicators of the amount of alimony paid as percent of the paying parent's income and the ratio of the distribution of the time spent by each parent for raising a child have been determined. For this, the first-order derivatives of the functions of these indicators' influence on the effectiveness of alimony obligations were used.

\section{RESULTS}

According to the results of the expert assessment (Table 1), it was determined that the most significant indicators when deciding on the amount of alimony deductions are indicators of the level of satisfaction of children's needs. This reflects the main purpose of alimony - the maintenance of minor children (Family Code of the Russian Federation, 1995). Significance coefficients for these indicators vary in the range of $0.08-0.14$. Parents' wellbeing indicators vary in the range of 0.01-0.07.

Table 1: Expert assessments regarding the significance of indicators of the level of parents' wellbeing and satisfaction of the child's needs when calculating the integral indicator of the effectiveness of alimony obligations

\begin{tabular}{|l|l|l|l|l|l|}
\hline Indicator & $\begin{array}{c}\text { Average rank } \\
\text { by group of } \\
\text { experts }\left(\boldsymbol{R} \boldsymbol{n}_{i}\right)\end{array}$ & $\begin{array}{c}\text { Significance } \\
\text { coefficient in } \\
\text { the integral } \\
\text { model }\left(\boldsymbol{k}_{\boldsymbol{i}}\right)\end{array}$ & Indicator & $\begin{array}{c}\text { Average rank } \\
\text { by group of } \\
\text { experts }\left(\boldsymbol{R} \boldsymbol{n}_{j}\right)\end{array}$ & $\begin{array}{c}\text { Significance } \\
\text { coefficient in } \\
\text { the integral } \\
\text { model }\left(\boldsymbol{k}_{j}\right)\end{array}$ \\
\hline$W 5$ & 10 & 0.04 & $N 11$ & 1 & 0.14 \\
\hline$W 6$ & 8 & 0.07 & $N 12$ & 2 & 0.13 \\
\hline$W 7$ & 9 & 0.05 & $N 13$ & 7 & 0.08 \\
\hline$W 8$ & 11 & 0.03 & $N 14$ & 3 & 0.12 \\
\hline$W 9$ & 13 & 0.01 & $N 15$ & 4.5 & 0.10 \\
\hline$W 10$ & 12 & 0.02 & $N 16$ & 4.5 & 0.10 \\
\hline- & - & - & $N 17$ & 6 & 0.09 \\
\hline
\end{tabular}

Source: Authors' finding

In order to test hypotheses $H 1-H 3$, regression models were built, the characteristics of which are presented in Table. 2. Checking the constructed models using the Chow test showed that there are differences in the nature of the influence of independent variables on the 
dependent variable in the context of the countries under study. The probability of the absence of structural breaks in the studied countries does not exceed 0.05 . In this regard, for modeling, we used sample populations formed based on the survey results separately for Russia, the USA, Germany, and France.

Table 2: Features of regression models reflecting the impact of alimony payments on the degree of satisfaction of the child's needs and parents' wellbeing

\begin{tabular}{|c|c|c|c|c|c|c|}
\hline \multirow[b]{2}{*}{ Model } & \multicolumn{6}{|c|}{ Model adequacy criteria } \\
\hline & $\mathrm{F}_{\text {emp. }}$ & $\mathrm{F}_{\text {cr. }}$ & $\mathbf{t}_{\text {emp. }}$ & $\mathrm{t}_{\mathrm{cr} .}$ & $\begin{array}{l}\text { Ramsey } \\
\text { Test } \\
\text { Prob. }\end{array}$ & $\begin{array}{l}\text { Normality } \\
\text { Test Prob. }\end{array}$ \\
\hline \multicolumn{7}{|l|}{ Russia } \\
\hline$I W_{(2)}=-0.13 \times R 30^{2}+0.05 \times R 30+0.49$ & 17.52 & 3.01 & $\geq|3.01|$ & 1.96 & 0.73 & 0.82 \\
\hline$I W_{(1)}=-5.10 \times R 30+2.08$ & 31.25 & 3.86 & $\geq|2.73|$ & 1.96 & 0.69 & 0.77 \\
\hline$I N=-2.99 \times R 30^{2}+1.85 \times R 30-0.05$ & 9.25 & 3.01 & $\geq|3.72|$ & 1.96 & 0.91 & 0.71 \\
\hline $\begin{array}{l}E F=-0.21 \times R 19^{2}+1.39 \times R 19-0.16 \times R 30^{2}+ \\
0.07 \times R 30-0.11 \times R 20^{2}+0.51 \times R 20- \\
0.41 \times R 21^{2}+2.05 \times R 21-1.10\end{array}$ & 39.52 & 1.96 & $\geq|4.58|$ & 1.96 & 0.59 & 0.83 \\
\hline \multicolumn{7}{|l|}{ The USA } \\
\hline$I W_{(2)}=-0.74 \times R 30^{2}+0.27 \times R 30+0.94$ & 52.46 & 2.62 & $\geq|3.21|$ & 1.96 & 0.85 & 0.51 \\
\hline$I W_{(1)}=-1.04 \times R 30+1.35$ & 39.00 & 3.86 & $\geq|3.73|$ & 1.96 & 0.92 & 0.80 \\
\hline$I N=-3.25 \times R 30^{2}+2.08 \times R 30+1.40$ & 36.72 & 2.62 & $\geq|3.93|$ & 1.96 & 0.79 & 0.73 \\
\hline $\begin{array}{l}E F=-0.19 \times R 19^{2}+1.63 \times R 19-0.24 \times R 30^{2}+ \\
0.09 \times R 30-0.14 \times R 20^{2}+0.59 \times R 20- \\
0.25 \times R 21^{2}+1.15 \times R 21+0.46\end{array}$ & 62.53 & 1.96 & $\geq|4.32|$ & 1.96 & 0.66 & 0.77 \\
\hline \multicolumn{7}{|l|}{ France } \\
\hline$I W_{(2)}=-0.89 \times R 30^{2}+0.28 \times R 30+0.88$ & 63.46 & 3.03 & $\geq|3.27|$ & 1.97 & 0.49 & 0.55 \\
\hline$I W_{(1)}=-2.05 \times R 30+1.40$ & 9.16 & 3.87 & $\geq|3.37|$ & 1.97 & 0.60 & 0.72 \\
\hline$I N=-3.62 \times R 30^{2}+2.53 \times R 30+1.11$ & 11.63 & 3.03 & $\geq|3.93|$ & 1.97 & 0.82 & 0.93 \\
\hline $\begin{array}{l}E F=-0.31 \times R 19^{2}+3.04 \times R 19-0.27 \times R 30^{2}+ \\
0.09 \times R 30-0.25 \times R 20^{2}+1.25 \times R 20- \\
0.36 \times R 21^{2}+1.87 \times R 21-6.83\end{array}$ & 31.00 & 1.97 & $\geq|4.73|$ & 1.97 & 0.91 & 0.89 \\
\hline \multicolumn{7}{|l|}{ Germany } \\
\hline$I W_{(2)}=-1.22 \times R 30^{2}+0.29 \times R 30+1.05$ & 26.42 & 3.02 & $\geq|4.01|$ & 1.97 & 0.57 & 0.71 \\
\hline$I W_{(1)}=-0.83 \times R 30+1.23$ & 28.66 & 3.86 & $\geq|3.81|$ & 1.97 & 0.72 & 0.68 \\
\hline$I N=-3.88 \times R 30^{2}+2.33 \times R 30+1.34$ & 37.25 & 3.02 & $\geq|3.94|$ & 1.97 & 0.73 & 0.72 \\
\hline $\begin{array}{l}E F=-0.16 \times R 19^{2}+1.31 \times R 19-0.33 \times R 30^{2}+ \\
0.10 \times R 30-0.16 \times R 20^{2}+0.64 \times R 20- \\
0.27 \times R 21^{2}+1.30 \times R 21+0.39\end{array}$ & 40.73 & 1.96 & $\geq|3.99|$ & 1.97 & 0.59 & 0.58 \\
\hline
\end{tabular}

$F_{\text {emp. }}$ is the empirical value of the F-test; $F_{c r}$ is the critical value of the F-test;

$t_{\text {emp. }}$ is the empirical value of the t-test; $t_{c r}$ is the critical value of the t-test;

Ramsey Test Prob. is the probability of correct classification of the type of regression model;

Normality Test Prob. is probability of distribution of the rest of the models according to the normal distribution law.

Source: Authors' finding

The empirical values of the F-test and t-test exceed the critical values at a significance level of 0.05. The Ramsey Test Prob. and Normality Test
Prob. exceed 0.05. These criteria indicate the adequacy of the constructed regression models. 
Based on the results of the developed regression models, it can be stated that the relationship between the percentage of alimony payments (in monetary terms) on the payer's income (indicator R3O) and indicators of the wellbeing of the parent who keeps the child $\left(I W_{(2)}\right)$ - the level of satisfaction of the child's needs $(I N)$ - has a quadratic function.

\section{DISCUSSION}

Based on the study, the nature of the dependencies of the level of alimony payments and the material wellbeing of the parent who pays them has been established empirically. An increase in the level of alimony payments up to a certain point leads to an increase in the wellbeing of the parent who keeps the child and the level of satisfaction of the child's needs. After that, the growth of the percentage of alimony deductions from the alimony payer's income will have the opposite effect. The revealed form of dependence can be explained by the action of the Laffer curve and the influence of similar factors in the formation of the identified pattern. An increase in the percentage of alimony payments leads to concealment of income and an artificial understatement of the base for alimony payments, since the parent becomes not interested in paying alimony in such amounts. As a result, an increase in the rate of deductions leads to payers' refusals to pay alimony and an increase in the number of claims for the recovery of alimony for a child. This confirms that the court settlement of the alimony payment is less effective than the contractual one.

The study has shown, the inversely proportional nature of the dependence of the level of satisfaction of the needs of children and the wellbeing of single-parent families is not a consequence of the manifestation of the poverty of the parents who pay alimony. On the contrary, it is their unwillingness to pay alimony. This conclusion is confirmed by the answers of $44 \%$ of respondents in Russia, who indicated an unwillingness to help their ex-spouse and unwillingness to transfer a significant percentage of their income as alimony as the main reasons for non-payment (late payment) of alimony (R29). For 21\% of respondents, such reasons are unwillingness to help their exspouse and unwillingness to communicate and help the child. The mentioned answer options are partially duplicated due to the fact that the question (R29) was supposed to have two answer options. For the USA, France, and Germany, the key reasons for non-payment of alimony are starting a new family, unwillingness to help an ex-wife (a spouse), and unwillingness to communicate and help the child, which is partially duplicated with the survey results in Russia. But, unlike Russia, cases of non-payment of alimony are less common. The value of the R28 indicator, which reflects the timeliness and completeness of alimony payment, in Russia was 2.1 points out of the maximum 5 points in Russia, 4 points in the USA, 4.4 points in France, and 4.7 points in Germany.

The regression model of the dependence of the level of parents' wellbeing on the percentage of alimony payments showed that, with an increase in the percentage of alimony payments by $1 \%$, the wellbeing of paying parents decreases by $1.58 \%$ in Russia, $0.15 \%$ in the USA, $0.28 \%$ in France, and $0.11 \%$ in Germany. This confirms the conclusion that the growth in alimony payments does not have a significant destabilizing effect on the payers' welfare. The constructed models only partially confirm hypothesis $H 3$, namely that:

1. There is a relationship between the percentage of alimony payments and the level of parents' wellbeing;

2. An increase in the percentage of alimony payments leads to decreases in the payer's wellbeing.

Hypothesis $H 3$ did not find confirmation that an increase in the percentage of alimony deductions from the payer's income contributes to an increase in the level of well-being of the parent who keeps the child, as stated in studies such as Hakovirta et al. (2019). This growth is observed until a certain point, after which an increase in alimony payments will lead to a decrease in both parents' wellbeing.

To test hypotheses $H 1$ and $H 2$ as independent variables in the models (Table 2), we used indicators of parents' involvement in raising children after divorce $(R 18, R 19, R 24)$ and opportunity costs for raising a child (R20-R23) in addition to the percentage of alimony deductions. 
Among the indicators of parents' involvement in children's upbringing, a statistically significant effect on the effectiveness of alimony obligations $(E F)$ is exerted by the indicator of the time of residence (spending time together) of a child with the parent paying alimony (R19). This confirms hypothesis $H 1$ that the alimony amount is determined not only by the amount of payments, but also by parents' participation in raising a child, which complements the research of Jeandidier \& Lim (2015).

For the $R 19$ indicator, the optimal value for Russia is 3.3 points, which corresponds to the ratio of the time spent by parents with the child $33 \times 67$ (33\% with the parent paying alimony according to the results of this survey, this is the father - and 67\% with the mother). For the United States, the optimal ratio is $43 \times 57$, for France, $49 \times 51$, and for Germany, 41×59. An increase in the $R 19$ indicator to the optimal level leads to an increase in all components of the integral indicator: the payer's welfare (due to the fact that an increase in the parent's intangible participation in raising a child can compensate for part of the material costs), the welfare of the parent, in favor of whom payments are made (due to freeing up a certain time previously engaged in raising a child, which can be used to earn and increase the level of wellbeing additionally), the level of satisfaction of the child's needs (by meeting the non-material needs in communication with both parents, minimizing feelings of inferiority and discomfort associated with divorce).

Based on the constructed regression models, the optimal indicators of alimony deductions were also determined, expressed as a percent of the payer's income, at which the integral indicator of the effectiveness of alimony obligations $(E F)$ is maximized by ensuring the welfare of the parents and the child, meeting the child's needs. The optimal values of the percentage of alimony payments vary in the range of $15-21 \%$ : for Russia, $21 \%$, the USA, $18 \%$, France, $17 \%$, and Germany, $15 \%$.

Among the opportunity cost indicators, the indicators $R 2 O$ (donation of education, work for the family and a child while being married) and $R 21$ (sacrifice for a career after divorce) have a statistically significant effect on the effectiveness of alimony obligations.
The presence in the regression model of assessing the effectiveness of alimony obligations of the indicators of alimony deductions and opportunity costs with the identical nature of influence demonstrates their positive effect on the dependent variable, and therefore the possibility of compensating one indicator at the expense of another. This confirms the $H 2$ hypothesis that the alimony payments depend on the professional choice made by each spouse during marriage for the sake of union or for the sake of children (opportunity costs).

\section{CONCLUSION AND RECOMMENDATIONS}

An approach is proposed to determine the amount of alimony payments that ensure a balance between meeting the minor child's needs and the wellbeing of divorced parents. The approach considers the economic dimensions (material component) used in determining the alimony amount (divorced parents' income level, the child's needs), and intangible aspects - the parents' contribution to raising children after a divorce and the opportunity costs associated with raising children.

The research results showed the need to consider many factors when determining the level of alimony payments in Russia for children living in single-parent families, namely: the time spent with the child; the level of parents' income; opportunity costs; and the child's needs.

Mental and national features have been identified that affect the alimony payment. In Russia, in comparison with the countries of Europe and the United States, the main destructive factors are still the unwillingness to pay alimony, reflecting the fact that one sees "enrichment" at the expense of a parentguardian. In view of this, it seems expedient to toughen administrative and criminal sanctions for alimony non-payment. But at the same time, the formation of a culture of divorce proceedings in Russia is also important, contributing to the development of the ability to cope with conflicts and get out of relationships with mature individuals who take responsibility for themselves and for their children's lives. The relevance and need for the development of the divorce process culture is also confirmed by the based dependence of the level of satisfaction of 
the child's needs and the amount of alimony payments, which is characterized by the Laffer curve.

It has been empirically determined that when the level of income of a parent who pays alimony is set at $21 \%$ in Russia, the level of satisfaction of the needs of a minor child living in an incomplete family is maximized and the risk of damage to the material wellbeing of the alimony is minimized. The optimal level of alimony payments in Russia in this study framework is determined to be somewhat higher (21\%) than in the studied countries of Europe and the United States, but this is due to the fact that in these countries, the government provides significantly more assistance to single-parent families to cover part of the costs associated with children, whether through tax subsidies or cash benefits, or through the provision of goods such as public education, health care, and transportation.

According to the research results, the optimal percentage of alimony payments for one child has been established and the influence of the number of children on the optimal percentage of alimony payments was not calculated. In view of the fact that these aspects require a more detailed analysis, they will be analyzed in our further studies.

\section{ACKNOWLEDGEMENT}

The research was carried out with the financial support of the Russian Foundation for Basic Research in the framework of the scientific project No. 19-011-00092.

\section{REFERENCES}

Alimony Laws by State. (2021). Marital Laws. https://www.maritallaws.com/laws/alimony

America's single-parent families. (2021). The Hill. https://thehill.com/opinion/finance/543941americas-single-parent-families

Australian Government. (2021). Services Australia. https://www.servicesaustralia.gov.au/

Beacon Family Law. (2021). https://www.beaconfamilylaw.com.au/servi ces/child-support/
Beaumont, K., \& Mason, P. (2014). Child maintenance systems in EU Member States from a gender perspective. European Parliament. https://www.europarl.europa.eu/RegData/et udes/note/join/2014/474407/IPOLFEMM_NT(2014)474407_EN.pdf

Citizen's Guide to U.S. Federal Law on Child Support Enforcement. (2020). U.S. Department of Justice. https://www.justice.gov/criminalceos/citizens-guide-us-federal-law-childsupport-enforcement

Comparative Law and Practices in Child Maintenance. (2015). http://pensionalimentaire.bardoutjc.fr/2015 /05/comparative-law-and-practices-inchild-maintenance/

Convention on the Rights of the Child. (1989). United Nations. https://treaties.un.org/Pages/ViewDetails.as px?src=TREATY\&mtdsg_no=IV-

$11 \&$ chapter $=4$

Dusseldorf Table. (2021). Scribd. https://ru.scribd.com/document/447331265 /Dusseldorf-Table-docx

Failure to pay child support. (2021). http://alimentyexpert.ru/neuplata/uklonenie/neuplataalimentov/

Family Code of the Russian Federation. (1995). Law of December 29, 1995 N 223-FZ. http://www.consultant.ru/document/cons_d oc_LAW_8982/

Federal bailiff service. (2021). https://fssp.gov.ru/

Federal State Statistics Service. (2021). https://rosstat.gov.ru/folder/12781

Filippova, E. (2020). United Russia proposed to toughen the liability for defaulters of alimony. Parliamentary Newspaper. https://www.pnp.ru/social/v-edinoy-rossiipredlozhili-uzhestochit-otvetstvennostdlya-neplatelshhikov-alimentov.html

Gesetz zur Sicherung des Unterhalts von Kindern alleinstehender Mütter und Väter durch Unterhaltsvorschüsse oderausfalleistungen (Unterhaltsvorschussgesetz). (2021). 
Bundesministerium der Justiz und für Verbraucherschutz. http://www.gesetze-iminternet.de/uhvorschg/_1.html

Google Form. (2021). Evaluation of the effectiveness collection of alimony for minor children.

https://docs.google.com/forms/d/e/1FAIpQL SfOhTHu4qZ8FOxc-

XUjQwKmC7UWyVollxAsbzTQkJTXpg47NQ/ viewform

Hair, J. F., Hult, G. M., Ringle, C. M., \& Sarstedt, M. (2017). A primer on partial least squares structural equation modeling (PLS-SEM). Thousand Oaks, CA: Sage Publications.

Hakovirta, M., Meyer, D.R., \& Skinner, C. (2019). Does paying child support impoverish fathers in the United States, Finland, and the United Kingdom? Children and Youth Services Review, 106, 104485. https://doi.org/10.1016/j.childyouth.2019.10 4485

Heggeness, M.L. (2020). Improving child welfare in middle income countries: The unintended consequence of a pro-homemaker divorce law and wait time to divorce. Journal of Development Economics, 143, 102405. https://doi.org/10.1016/j.jdeveco.2019.1024 05

Jeandidier, B., \& Lim, H. (2015). Is there justification for alimony payments? A survey of the empirical literature. hal02105214. https://hal.archivesouvertes.fr/hal-02105214/document

Judicial Department at the Supreme Court of the Russian Federation. (2021). http://www.cdep.ru/index.php?id=79

Kobrina, E. (2021). Child support in 2021. https://www.b-kontur.ru/enquiry/257\#

Komrakov, A. (2021). Envelope wages save the Russian economy. https://www.ng.ru/economics/2021-0527/4_8159_economics.html

La pension alimentaire. (2021). Ministère de la Justic.

https://www.justice.fr/themes/pensionalimentaire

Maghlaperidze, E., Kharadze, N., \& Kuspliak , H. (2021). Development of Remote Jobs as a Factor to Increase Labor Efficiency. Journal of Eastern European and Central Asian Research (JEECAR), 8(3), 337-348. https://doi.org/10.15549/jeecar.v8i3.669

Morgan, L. W. (2021). Child Support Guidelines: Interpretation and Application. $\mathrm{CCH}$ Incorporated. New York

Neither ruble, nor penny. Why is it so difficult to get child support? (2021). https://www.severreal.org/a/31147033.html

New York Child Support Lawyer. (2021). NYC Family Law Attorney Stephen Bilkis \& Associates. https://familylawyer.1800nynylaw.com/ne w-york-child-support-lawyer.html

Pirtskhalaishvili, D., Paresashvili, N., \& Kulinich, $\mathrm{T}$. (2021). The gender aspects of career development and leadership in organizations. Journal of Eastern European and Central Asian Research (JEECAR), 8(2), 255 - 266. https://doi.org/10.15549/jeecar.v8i2.654

Taherdoost, H. (2017). Determining Sample Size; How to Calculate Survey Sample Size. International Journal of Economics and Management Systems, 2, 237-239.

The Criminal Code of the Russian Federation. (1996). Law of June 13, 1996 N 63-FZ. http://www.consultant.ru/document/cons_d oc_LAW_10699/

Van Winkle, Z., \& Leopold, T. (2021). Family size and economic wellbeing following divorce: The United States in comparative perspective. Social Science Research, 96, 102541. https://doi.org/10.1016/j.ssresearch.2021.10 2541

World Population Review. (2021). https://worldpopulationreview.com/country -rankings/divorce-rates-by-country 


\section{ABOUT THE AUTHORS}

Yulia A. Artemyeva, email:

artemyevayulia@yandex.ru

Yulia A. Artemyeva, obtained her initial higher technical education in BMSTU (Bauman Moscow State Technical University), specialty: Mechanical Engineer; and higher legal education in the Moscow State Law Academy with a degree in Jurisprudence with qualification as Lawyer. Yulia A. Artemyeva has a $\mathrm{PhD}$ in Law. She works as Associate Professor of the Department of Civil Law and Procedure and International Private Law at the Law Institute of the Federal State Autonomous Educational Institution of Higher Education Peoples' Friendship University of Russia (RUDN University). She combines scientific and teaching work with practical work. Dr. Artemyeva is the author of over two hundred articles in scientific journals, and three monographs. 